How to Cite: Seitmagzimova, G.M., Assylkhankyzy, A., Petropavlovsky, I.A., \& Dzhanmuldaeva, Zh.K.. (2021) Research of the process of obtaining potassium fertilizers from carnallite ore. Bulletin of the University of Karaganda - Chemistry, 102(2), 77-85. https://doi.org/10.31489/2021Ch2/77-85

\author{
G.M. Seitmagzimova*1, A. Assylkhankyzy ${ }^{1}$, I.A. Petropavlovsky², Zh.K. Dzhanmuldaeva ${ }^{1}$ \\ ${ }^{1}$ M. Auezov South Kazakhstan University, Shymkent, Kazakhstan; \\ ${ }^{2}$ D. Mendeleev University of Chemical Technology of Russia, Moscow, Russia \\ (*Corresponding author's e-mail: galinaseit@mail.ru)
}

\title{
Research of the process of obtaining potassium fertilizers from carnallite ore
}

\begin{abstract}
To provide domestic and foreign markets with potash fertilizers Kazakhstan has begun to create own production of these products. But at the moment enterprises engaged in mining potash salts did not reach a practical stage. The Chelkarcarnallite ore deposit is a unique one in solving these urgent problems. The article presents results of the study of processing Chelkar potash ore washed from sodium chloride to obtain a potassium fertilizer containing potassium and magnesium sulfates. The kinetics of nitric acid decomposition of carnallite ore has been investigated. The calculated value of reaction activation energy of potassium sulfate and nitric acid interaction characterizes the kinetic region of the process behavior. Optimal conditions for decomposition of washed calcined ore with $30 \%$ nitric acid solution at $50{ }^{\circ} \mathrm{C}$ were determined. It has been found that to ensure better filtration properties and high rate of suspension separation, washed non-calcined ore should be used to exclude gypsum dehydration, which causes its phase conversion into anhydrite. The double salt of potassium-magnesium sulfate was separated by crystallization from nitric acid extract and an ammoniated mother liquor drying allowed to obtain a salt, which is ballast-free chlorine-free complex nitrogen-potassium-magnesium fertilizer.
\end{abstract}

Keywords: potash ore, mineral fertilizer, potassium sulfate, sodium salts, Chelkar deposit, mother liquor, decomposition, evaporation, crystallization.

\section{Introduction}

Application of potash fertilizers along with phosphorus and nitrogen ones is essential for sustainable crop yields, and it is one of main indicators of agricultural development in a country. Among them, sulfate potash fertilizers are most suitable for crops in Southeast Asia, which is the main consumer of potash fertilizers in the world. From an agrochemical point of view, this type of fertilizer is of particular value, since many agricultural crops, such as potatoes, tomatoes, cabbage, peas, flax, soybeans react negatively to the chlorine presence in the soil [1].

Total reserves of potash salts in the world are estimated about 40 billion tons, Canada, Russia, Belarus, and Germany are main potash producers [2]. The Central Asian region of the CIS countries also has significant reserves of potassium-bearing ores. In this regard, to provide domestic and foreign markets with competitive potash fertilizers a number of countries in this region (Kazakhstan, Turkmenistan, Uzbekistan) have intensified efforts to create own production of these compounds in recent years. The interest of the region countries in potash fertilizer production is also determined by the proximity of large markets for products (China, India, etc.) [2].

According to academic data, potash salts are abundant in the Caspian Basin in Kazakhstan. Composition of the salts is predominantly chloride, their beds are found in the arches of many salt domes practically throughout the entire territory of the basin. "Satimola", "Chelkar", "Inder", and "Zhilyanskoe" are the most studied domes [3]. The project of Kazakhstan Potash corporation (China) on creation of an enterprise for mining the potash salts and their processing into fertilizers in Kazakhstan has not yet turned into a practical stage [4]. Among them Chelkar is a rather complex deposit: a layered salt dome containing several minerals: sylvinite, carnallite, bischofite, halite, borate, etc. [5]. Carnallite is a main component of this ore, which consists of two compounds of chlorine with potassium and magnesium. It is a mineral of medium abundance and sedimentary origin. Sylvinite rock is formed as combination of sylvite, halite and other salts. In terms of mineral composition, carnallite ore contains up to $65 \%$ carnallite, 5-15\% of sylvite and $15-25 \%$ of halite. Carnallite ore compares favorably with sylvinite in its composition, it contains a wider range of salts.

Currently there is no technology for processing the Chelkar deposit ore, therefore development of domestic production of potash fertilizers based on this raw material is an urgent problem. To solve these problems it is necessary to carry out a complex studies on processing the natural salts, which are a complex salt system. 
Previously we have determined the following average chemical composition of the ore, mass $\%: \mathrm{Na}_{2} \mathrm{O}-$ 8.47; $\mathrm{K}_{2} \mathrm{O}-14.04 ; \mathrm{CaO}-7.72 ; \mathrm{MgO}-5.55 ; \mathrm{SO}_{4}{ }^{2-}-26.58 ; \mathrm{Cl}^{-}-18.77$ [6]. Based on the chemical composition and X-ray diffraction patterns, the mineralogical composition of carnallite ore was determined, which showed the heterogeneity of this salt and presence of both water-soluble components in the form of carnallite, glaserite and halite, and insoluble calcium sulfatein its composition [6]. In this regard, the possibility of enriching the Chelkar ore for potassium was studied due to preliminary washing of the impurity mineral halite as a salt with a higher solubility. The results of an experiment on washing ore by incomplete dissolution showed that this is an effective method for removing highly soluble sodium salts from the composition of raw materials (impurity components in potash fertilizers). The obtained data on the degree of ore washing from sodium salts allowed to propose a washing mode for 20 minutes at a mass ratio of water : salt equal to $1: 2$, which ensures minimal losses of valuable potassium with washing water [7]. Further, the optimal enrichment mode was worked out using a mother liquor, for two-fold washing of the original ore to achieve maximum washing degree from sodium with a potassium saturated solution. As a result of washing, almost all of the sodium chloride was removed from the ore with the keeping potassium and magnesium sulfates, as evidenced by the results of X-ray phase analysis. For further processing of the washed ore into fertilizers the obtained sample was calcined at $550{ }^{\circ} \mathrm{C}$, then subjected to dissolution in water at temperatures of 50 and $90{ }^{\circ} \mathrm{C}$. The results of this study showed that it leads to only a partial transition of potassium and magnesium sulfates to a solution with complete dissolution of residual amounts of sodium salts [8]. Therefore, to obtain chlorine-free water-soluble mineral fertilizer containing potassium and magnesium sulfates it is necessary to search for other chemical methods for processing the concentrated ore.

\section{Experimental}

There are known methods of processing polyhalite ores of various deposits on the territory of Russian Federation using nitric acid, which have shown high efficiency of transferring salts into solution with insoluble residue separation [9]. Therefore, the process of dissolution of washed calcined potash ore of above composition with nitric acid solution in the concentration range of $10-50 \%$ at salt : acid ratio $1: 1.5$ at temperature of $50{ }^{\circ} \mathrm{C}$ was studied. The kinetics of ore decomposition with $10 \%$ nitric acid was preliminarily studied by composition of liquid and solid phases in the range of 10-40 minutes. The process was carried out in thermostated glass reactor with a stirrer under the exhaust ventilation turned on with sampling from the side neck of the reactor. At the end of the decomposition, the suspension was separated in a vacuum filtration unit with 0.06 $\mathrm{MPa}$, the precipitate was washed with hot water; filtration productivity was determined by a dry washed precipitate. Composition of liquid and solid phases was analyzed for $\mathrm{K}_{2} \mathrm{O}$ and $\mathrm{Na}_{2} \mathrm{O}$ content using a PFA-378 flame photometer, the content of $\mathrm{CaO}, \mathrm{MgO}, \mathrm{Cl}^{-}, \mathrm{SO}_{4}{ }^{2-}$ and $\mathrm{N}$ was determined by chemical titrimetric method according to standard procedures.

All studies of potassium ore decomposition by nitric acid solution were double-checked for different process conditions. Total standard uncertainty of measurement and standard deviation for analyses of liquid and solid phase composition was calculated of 3 parallel sample measurements taking into account sample weighing, calibration and measurement on the flame photometer. For measurement of $\mathrm{K}_{2} \mathrm{O}$ content in the solid phase obtained at nitric-acid decomposition the total standard uncertainty was 0.0067 . Relative standard deviation from the averaged value with a confidence level $\mathrm{P}=0.95$ was 0.0061 .

Crystallization of potassium-magnesium salts was carried out by mineral-salt method, taking into account the initial solution composition and crystallization fields on the solubility diagram in $\mathrm{K}_{2} \mathrm{SO}_{4}-\mathrm{MgSO}_{4}-\mathrm{H}_{2} \mathrm{O}$ system. The solution was evaporated at a constant temperature of $75{ }^{\circ} \mathrm{C}$ in UT-4302E laboratory water bath. The precipitated crystals were separated by filtration, washed with ethanol, and examined by X-ray analysis. The mother liquor was ammoniated to $\mathrm{pH}=6$ and dried in a dryer at $60{ }^{\circ} \mathrm{C}$. Scanning electron microscope JSM-64901 (Jeol, Japan) was used for microscopic spectral analysis of salts. Semi-quantitative X-ray analysis of solid phase samples was carried out on D8 Advance (Bruker) apparatus with $\mathrm{Cu}-\mathrm{K}_{\alpha}$ at tube voltage $40 \mathrm{kV}$ and current $40 \mathrm{~mA}$. Processing of the obtained data of diffraction patterns and calculation of interplanar distances were carried out using the EVA software. Sample decoding and phase search were performed using Search/match program with the use of $2020 \mathrm{PDF}-2$ powder diffractometric data base of the International Center for Diffraction Data (ICDD), USA.

\section{Results and Discussion}

The results of studying nitric acid decomposition of washed potash ore are shown in Figure 1 and Table 1. The kinetic dependences (Fig. 1) of potassium and magnesium salts dissolution show that the composition of 
liquid and solid phases in terms of potassium and magnesium reaches equilibrium by 30 minutes of decomposition, and the process rate for potassium is higher in the first 10 minutes.

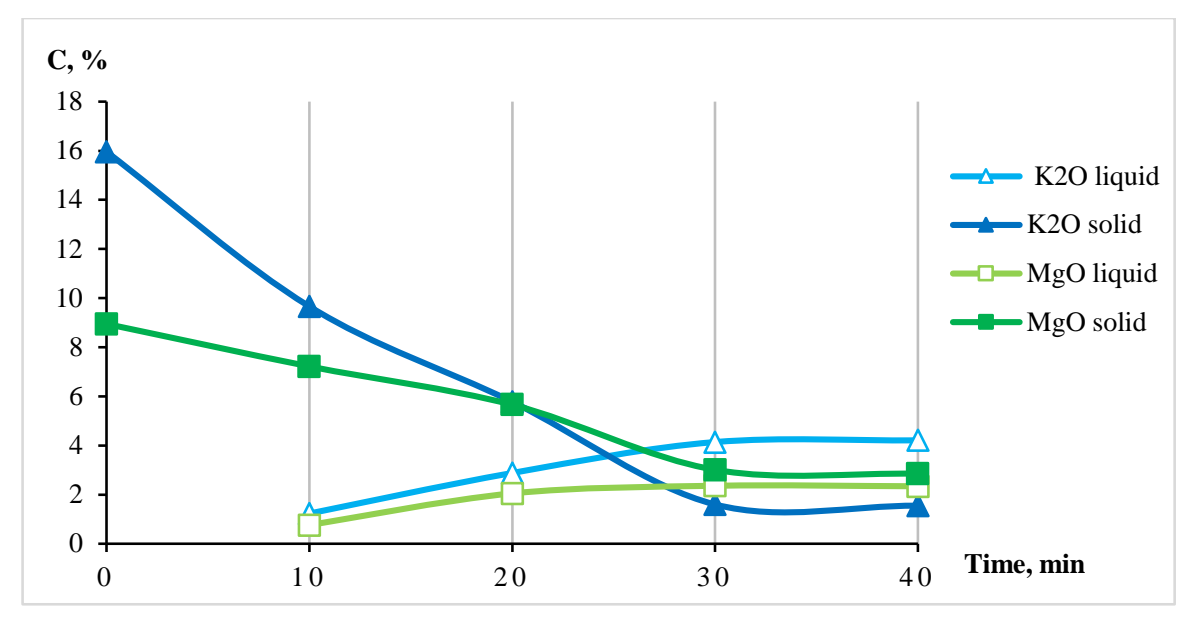

Figure 1. Kinetics of nitric acid decomposition of potash ore

Thus, at 30 minutes the solution contains $4.14 \% \mathrm{~K}_{2} \mathrm{O}$ and $2.36 \% \mathrm{MgO}$, and further this content is not practically changed. Accordingly, the content of these components in the solid phase decreases by the thirtieth minute to a minimum value of $1.6 \% \mathrm{~K}_{2} \mathrm{O}$ and $3.01 \% \mathrm{MgO}$, i.e., the equilibrium is reached. Therefore, it is effectually to choose 30 minutes time for the washed ore decomposition.

The process kinetic parameters were calculated; on the basis of experimental data, the order of reactions proceeding in this process was determined:

$$
\begin{gathered}
\mathrm{K}_{2} \mathrm{SO}_{4}+2 \mathrm{HNO}_{3} \leftrightarrow 2 \mathrm{KNO}_{3}+\mathrm{H}_{2} \mathrm{SO}_{4} \\
\mathrm{MgSO}_{4}+2 \mathrm{HNO}_{3} \leftrightarrow \mathrm{Mg}\left(\mathrm{NO}_{3}\right)_{2}+\mathrm{H}_{2} \mathrm{SO}_{4}
\end{gathered}
$$

The order of these reactions was determined by Van 't Hoff method [10] in the time interval of 10-40 minutes at $50{ }^{\circ} \mathrm{C}$ at the following changing main components concentration in the solution: from $0.13 \mathrm{~mol} / 1$ to $0.45 \mathrm{~mol} / \mathrm{l}$ for $\mathrm{K}_{2} \mathrm{O}$, and from $0.19 \mathrm{~mol} / 1$ to $0.58 \mathrm{~mol} / \mathrm{l}$ for $\mathrm{MgO}$. Reaction rates were calculated using graphic differentiation method by the tangent to the $C=f(\tau)$ dependence. It was found that 1 st and 2 nd were of the first order reactions. Therefore the reaction rate is described by the first order equation $V=k \cdot C$ for each of the components. The reaction rate constant calculated for potassium oxide as a main component was $0.09 \mathrm{~min}^{-1}$ at a temperature of $50{ }^{\circ} \mathrm{C}$. To determine reaction activation energy in the optimal mode, the process kinetics was calculated in a similar way for a temperature of $40^{\circ} \mathrm{C}$, for which the reaction rate constant was $0.03 \mathrm{~min}^{-1}$. We apply the Arrhenius equation, expressing dependence of the reaction rate on temperature:

$$
k=k_{0} e^{-\frac{E}{R T}},
$$

where $k$ - reaction rate constant; $k_{0}$ - pre-exponential multiplier (calculates the number of molecule collisions, their special orientation and other factors that do not depend on temperature); $R$ - universal gas constant; $E$ - reaction activation energy.

In the reaction (1) activation energy $E=92.22 \mathrm{KJ} /$ mole have been determined by solving the equations for two temperatures. The process rate was determined by the rate of chemical reaction, which increases at temperature growing and does not depend on diffusion stage rate [11]. When potassium ion maximum concentration is reached in the solution, the system comes to a state of equilibrium, and potassium, magnesium, sulfate and nitrate ions are in equilibrium in the formed solution. Therefore, to study the effect of nitric acid solution concentration on the extraction degree of potassium salts into the solution, $50{ }^{\circ} \mathrm{C}$ was chosen as the optimum process temperature, which provides the maximum process rate. A higher temperature was not expedient because of acid increased fuming due to accelerating its decomposition with nitrogen oxide release.

Composition of nitric acid extract obtained in the optimal temperature-time mode after separation into liquid and solid phases (Table 1) showed that, upon decomposition with $10 \%$ nitric acid, a part of potassium $\left(1.6 \% \mathrm{~K}_{2} \mathrm{O}\right)$, remained in the original salt. The increase of nitric acid concentration to $30 \%$ leads to $100 \%$ extraction degree of potassium salts into a solution is reached; and liquid phase contains $4.51 \%$ of $\mathrm{K}_{2} \mathrm{O}$. At the same time, sulfate ion content increases in the solution from $10.12 \%$ to $10.9 \%$ and $\mathrm{MgO}$ content also grows from 2.36 to $2.54 \%$. 


\section{Influence of nitric acid concentration on phases'composition after calcined ore decomposition}

\begin{tabular}{|c|c|c|c|c|c|}
\hline \multicolumn{2}{|c|}{$\begin{array}{l}\text { Composition of cal- } \\
\text { cined washed ore }\end{array}$} & \multirow{2}{*}{$\begin{array}{c}\text { Post- } \\
\text { decomposition } \\
\text { phase }\end{array}$} & \multicolumn{3}{|c|}{$\begin{array}{c}\text { Component content in phases, } \% \\
\text { at } \mathrm{HNO}_{3} \text { concentration }\end{array}$} \\
\hline Component & $\%$ & & $10 \%$ & $30 \%$ & $50 \%$ \\
\hline \multirow{2}{*}{$\mathrm{K}_{2} \mathrm{O}$} & \multirow{2}{*}{15.96} & solid & 1.60 & 0 & 0 \\
\hline & & liquid & 4.14 & 4.51 & 4.41 \\
\hline \multirow{2}{*}{$\mathrm{CaO}$} & \multirow{2}{*}{19.30} & solid & 25.20 & 29.40 & 29.21 \\
\hline & & liquid & 0.22 & 0.06 & 0.05 \\
\hline \multirow{2}{*}{$\mathrm{MgO}$} & \multirow{2}{*}{8.95} & solid & 3.01 & 5.00 & 5.63 \\
\hline & & liquid & 2.36 & 2.54 & 2.70 \\
\hline \multirow{2}{*}{$\mathrm{SO}_{4}{ }^{2-}$} & \multirow{2}{*}{62.12} & solid & 54.80 & 61,11 & 64.23 \\
\hline & & liquid & 10.12 & 10.90 & 8.76 \\
\hline
\end{tabular}

Sodium ion absence is associated with preliminary complete ore washing from sodium and chloride ions. At that, calcium oxide is practically absent in the liquid phase and its content is determined by solubility in nitric-acid extract, therefore all calcium is completely bound in the form of insoluble calcium sulfate, represented by anhydrite and gypsum. This fact is confirmed by the X-ray diffraction pattern of the insoluble residue, which consists entirely of the indicated salts (Fig. 2).

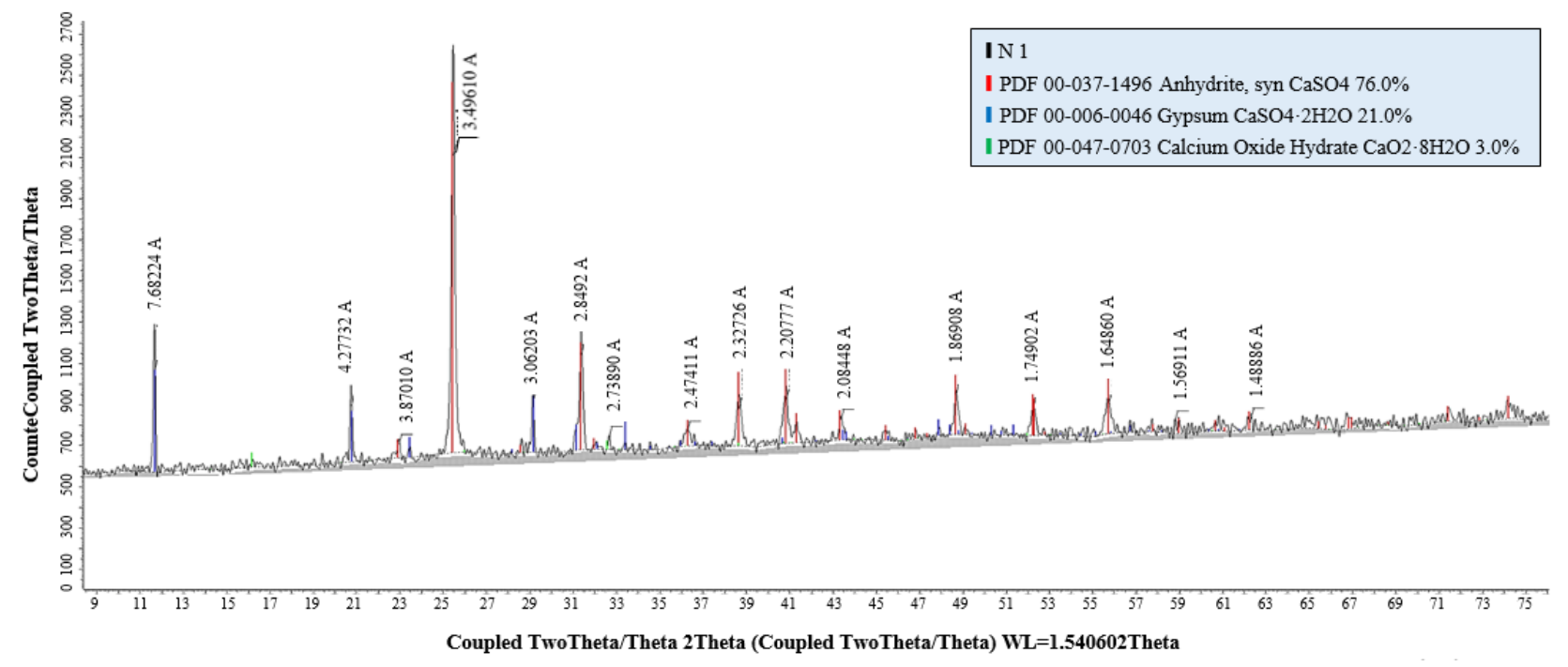

Figure 2. X-ray diffraction pattern of the insoluble residue after nitric acid decomposition of raw materials

Further increase of nitric acid concentration leads to a slight decline of potassium oxide content in the solution; it can be explained by salting out with magnesium salts, of content which increases to $2.7 \%$. Simultaneously, sulfate ions content in the liquid phase decreases and these ions content increases in the solid phase; it is also caused by salting out of magnesium sulfate. The results obtained allow to conclude that $30 \%$ nitric acid should be used to decompose the washed ore.

Filtration productivity of nitric acid extract is $160 \mathrm{~kg} / \mathrm{m}^{2} \cdot \mathrm{h}$ on dry precipitate; low precipitate filterability is obviously associated with gypsum phase transition into waterless anhydrite during washed ore calcination. This transition is also indicated by the precipitate composition on the X-ray diffraction pattern, which determined $\mathrm{CaSO}_{4}$ content as $76 \%$ and $\mathrm{CaSO}_{4} \cdot 2 \mathrm{H}_{2} \mathrm{O}$ content as $21 \%$. It is known that anhydrite is formed as small crystals, which determine precipitate filtration properties. Crystals clog filter pores and significantly increase filtration time. Since insoluble residue filtration is a limiting stage [12], conditions should be chosen to increase filtration productivity and accelerate the process. For this, an additional study of washed ore decomposition was carried out, and it was not subjected to preliminary calcination. In this case, gypsum dehydration does not occur and it can improve the precipitate filtration properties. The result of this decomposition and subsequent filtration showed an increase in filtration productivity by 20 times, up to $3200 \mathrm{~kg} / \mathrm{m}^{2} \cdot \mathrm{h}$ on dry washed 
precipitate. It confirms an assumption about gypsum content in the precipitate. The water obtained after washing the insoluble residue was used to dilute nitric acid to the required concentration.

The production solution obtained in optimal decomposition mode contains $8.34 \%$ of $\mathrm{K}_{2} \mathrm{SO}_{4}, 7.62 \%$ of $\mathrm{MgSO}_{4}$, and $2.03 \%$ of $\mathrm{N}$. Crystals isolated by an isothermal method, i.e., by partial evaporation of the filtrate to half the volume after washing were subjected to X-ray phase analysis. X-ray analysis of the obtained salt (Fig. 3) identified a pure double acidic salt of potassium-magnesium sulfate $\mathrm{KMgH}\left(\mathrm{SO}_{4}\right)_{2} \cdot \mathrm{H}_{2} \mathrm{O}$. This indicates that upon evaporation at a temperature of $75^{\circ} \mathrm{C}$ a point of the system composition was in the field of joint crystallization of potassium sulfate and this double salt. This composition is confirmed by elemental analysis and a spectrogram of the salt obtained on SEM (Fig. 4). Carbon content in the sample is determined by thorough washing this water-soluble salt from a mother liquor with ethanol.

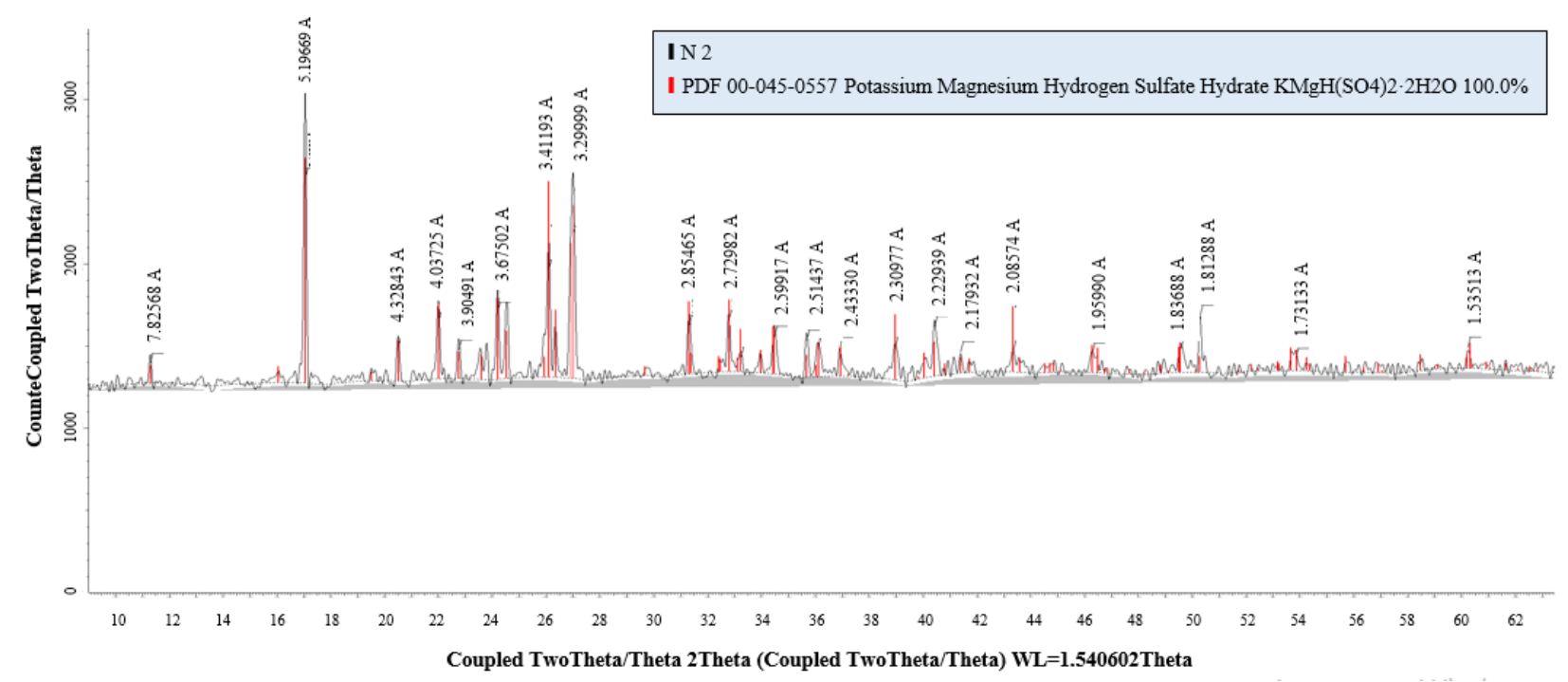

Figure 3. X-ray diffraction pattern of the salt obtained by isothermal crystallization from the filtrate

\begin{tabular}{|l|l|}
\hline Element & Mass \% \\
\hline $\mathrm{C}$ & 5.35 \\
\hline $\mathrm{O}$ & 53.75 \\
\hline $\mathrm{Mg}$ & 6.19 \\
\hline $\mathrm{S}$ & 19.69 \\
\hline $\mathrm{K}$ & 15.01 \\
\hline Total & 100.00 \\
\hline
\end{tabular}

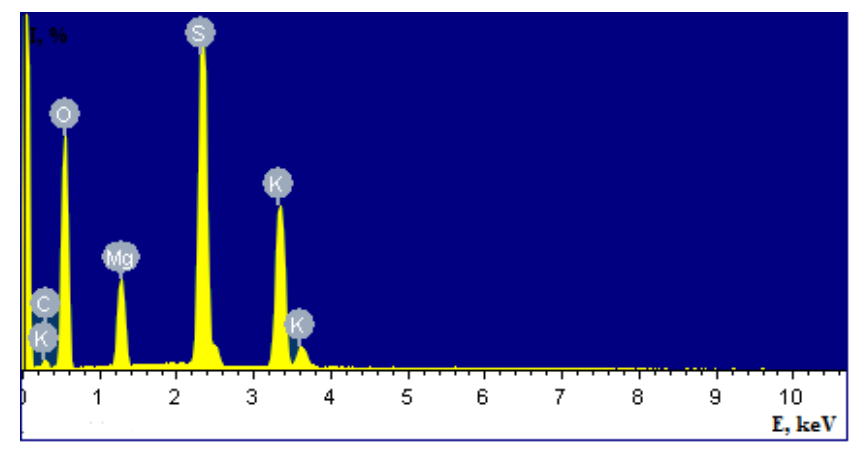

Figure 4. Spectrogram and element composition of the crystallized salt

White crystalline product contains $18.0 \%$ of $\mathrm{K}_{2} \mathrm{O}$ and $10.3 \%$ of $\mathrm{MgO}$ in the form of sulfates; it does not include chloride ions and insoluble impurities, but contains a small amount of free nitric acid. Acidic mineral fertilizer cannot be used on physiologically acidic and neutral soils, therefore the production solution was ammoniated to $\mathrm{pH}=6$ to obtain a neutral product. After drying the ammoniated solution, a pale yellow-green close to white solid product was obtained. The product composition was determined by X-ray phase analysis (Fig. 5).

The production salt has $\mathrm{pH}=6.0$, does not contain insoluble impurities and chlorine; it is completely water-soluble salt consisting of potassium-ammonium nitrate $\mathrm{KNO}_{3} \cdot \mathrm{NH}_{4} \mathrm{NO}_{3}(48.7 \%)$, crystalline hydrate magnesium-ammonium sulfate $\left(\mathrm{NH}_{4}\right)_{2} \mathrm{Mg}\left(\mathrm{SO}_{4}\right)_{2} \cdot 6 \mathrm{H}_{2} \mathrm{O}(38.9 \%)$ and ammonium nitrate (12.4\%). This is also indicated by the spectrogram of this product obtained on the SEM (Fig. 6). 


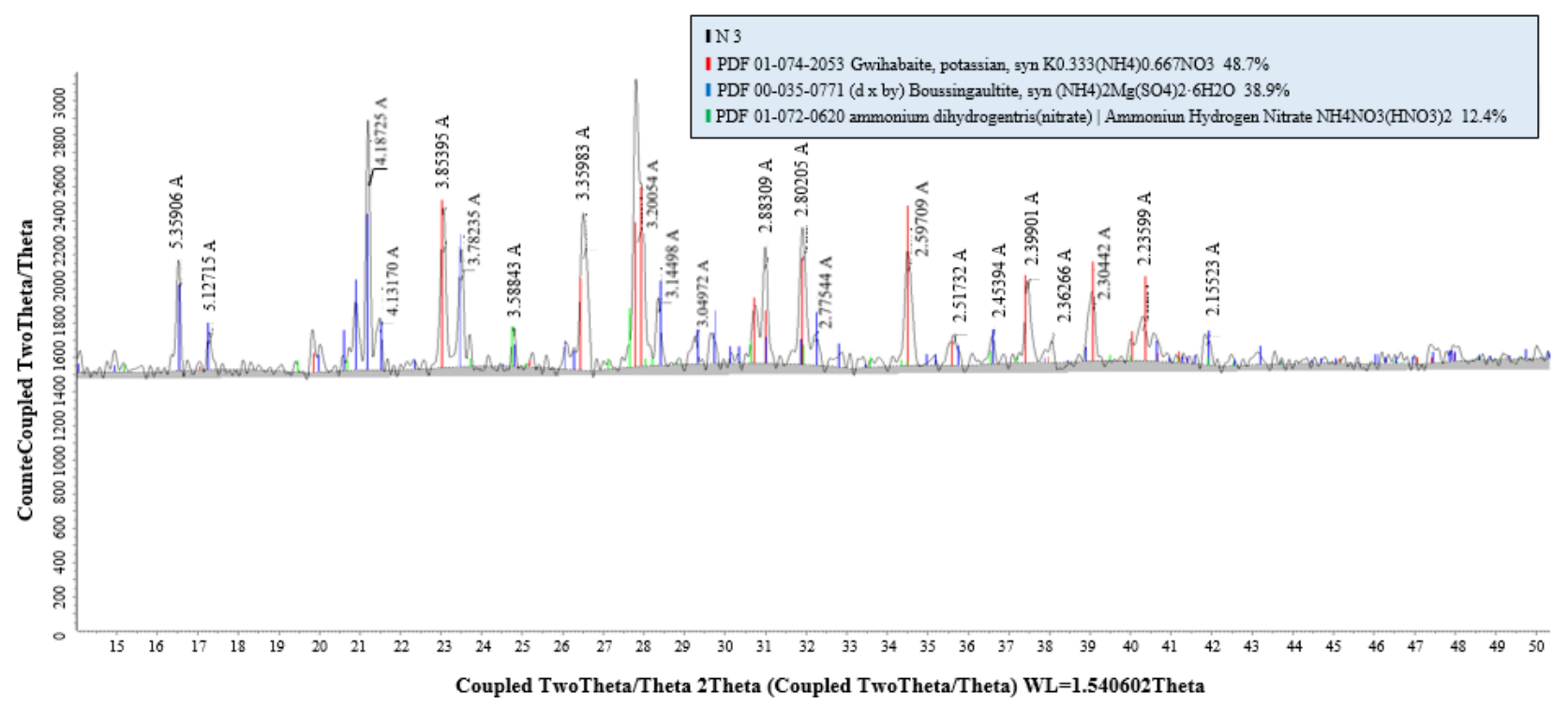

Figure 5. X-ray diffraction pattern of the salt obtained by drying the product solution

\begin{tabular}{|l|l|}
\hline Element & Mass \% \\
\hline $\mathrm{C}$ & 8.85 \\
\hline $\mathrm{N}$ & 17.03 \\
\hline $\mathrm{O}$ & 49.96 \\
\hline $\mathrm{Na}$ & 0.42 \\
\hline $\mathrm{Mg}$ & 3.01 \\
\hline $\mathrm{Al}$ & 0.23 \\
\hline $\mathrm{P}$ & 0.22 \\
\hline $\mathrm{S}$ & 7.84 \\
\hline $\mathrm{Cl}$ & 0.25 \\
\hline $\mathrm{K}$ & 11.49 \\
\hline $\mathrm{Ca}$ & 0.69 \\
\hline Total & 100.00 \\
\hline
\end{tabular}

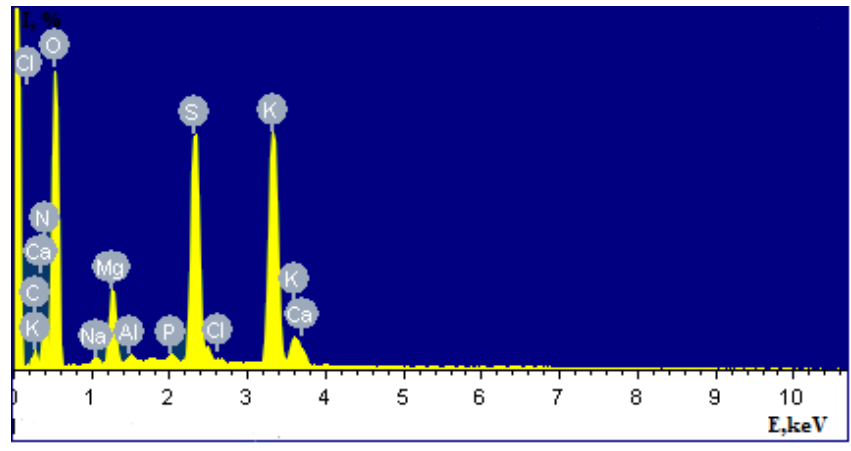

Figure 6. Spectrogram and element compositionof the target salt

The product contains: potassium (11.49\%), magnesium $(3.01 \%)$, sulfur $(7.84 \%)$ and nitrogen $(17.03 \%)$ on average with $9-13 \%$ deviation corresponds to the above salt composition. The presence in the composition of an insignificant fraction of chloride ions $(0.25 \%)$, sodium ions $(0.42 \%)$ and calcium $(0.69 \%)$ is within the solubility of these ions in the product solution from which the salt is obtained. The ratio of main nutrients in the obtained fertilizer $\mathrm{N}: \mathrm{K}$ was 1.5:1, taking into account the following microelements $\mathrm{N}: \mathrm{K}: \mathrm{S}: \mathrm{Mg}=1.5: 1: 0.7: 0.3$. The obtained product was a complex potassium-nitrogen-magnesium water-soluble chlorine-free ballastless fertilizer, the main salt components of which were potassium nitrate, magnesium sulfate, nitrate and ammonium sulfate.

\section{Conclusions}

The kinetics of nitric acid decomposition of carnallite ore from the Chelkar deposit was studied in order to obtain chlorine-free water-soluble potassium fertilizer. It was found that the equilibrium in potassium and magnesium in liquid and solid phases was reached to 30 minutes of decomposition. The first order of the reactions was determined by calculation. The calculated value of reaction activation energy for interaction of potassium sulfate with nitric acid $E_{a}=92.22 \mathrm{KJ} / \mathrm{mol}$ characterizes kinetic region of the process. The research results allowed to determine the optimal mode of washed potash ore decomposition, which ensures the complete extraction of potassium into the liquid phase: temperature $50{ }^{\circ} \mathrm{C}$, concentration of nitric acid $30 \%$. The study of nitric acid extract filtration productivity showed that to ensure better filtration properties and high rate of suspension separation, the washed non-calcined ore should be used to exclude gypsum dehydration, which causes its phase transition into anhydrite. Mineral potassium-magnesium sulfate fertilizers were obtained by 
crystallization from nitric acid solution by the isothermal method and by drying the ammoniated solution. The composition of obtained products was identified by X-ray analysis.

\title{
References
}

1 Земсков А.Н. Тенденции развития калийной промышленности на современном этапе / А.Н. Земсков // Тр. Нац. центра комплексной переработки минерального сырья Республики Казахстан. — 2013. — № 1. — С. $209-222$.

2 Турко М.Р. Разработка технологии обогащения калийной руды месторождения Сатимола (Республика Казахстан) / М.Р. Турко, Е.М. Миськов, А.С. Стромский, Т.И. Касенов, К.В. Сивцов // Горн. журн. — 2014. — № 2. - С. 87-89.

3 Корнева О. Казахстан: на земном шаре нет таких месторождений, где бораты смешаны с магниевыми и калиевыми солями / О. Корнева [Электронный ресурс]. - Режим доступа: https://kazakh-zerno.net/10009-kazakhstan-na-zemnom-share-nettakikh-mestorozhdenij-gde-boraty-smeshany-s-magnievymi-i-kalievymi-solyami/

4 Савинский Д. Казахстан пытается пробиться в глобальный калийный клуб / Д. Савинский [Электронный ресурс]. Режим доступа: https://www.fertilizerdaily.ru/20171205-kazaxstan-ne-mozhet-probitsya-v-globalnyj-kalijnyj-klub/

5 Тен С. Запасов хватит лет на сто / С. Тен // Горно-металлургическая промышленность. - 2016. — № 7. — С. 32-34.

6 Сейтмагзимова Г.М. Переработка карналлитовых руд месторождения Челкар / Г.М. Сейтмагзимова, А.Н. Усенова, А. Асылханқызы, А.А. Сейтмагзимов // Науч. тр. ЮКГУ им. М. Ауэзова. — 2018. — № 4 (48). — С. $178-182$.

7 Асылханқызы А. Исследование способов переработки калийных руд месторождения Челкар / А. Асылханқызы, Г.М. Сейтмагзимова, М. Петров, Ж.К. Джанмулдаева // Вестн. Казахстан.-Британ. техн. ун-та. — 2020. — № 2 (53). C. $44-52$.

8 Асылханқызы А. Оптимизация процесса обогащения калийной руды месторождения Челкар / А. Асылханқызы, Г.М. Сейтмагзимова, И.А. Петропавловский // Вестн. Казахстан.-Британ. техн. ун-та. — 2021. — № 1(18). — С. 39-47.

9 Стефанцова О.Г. Исследование технологии получения сульфатных калийно-магниевых удобрений из полигалитовых руд / О.Г. Стефанцова, В.А. Рупчева, В.3. Пойлов // Вестн. ПНИПУ. Химическая технология и биотехнология. — 2014. № 1 . - С. 65-74.

10 Колинько П.А. Химическая кинетика в курсе физической химии: конспект лекций: учеб.-метод. пос. / П.А. Колинько, Д.В. Козлов. - Новосибирск: НГУ, 2013. - 99 с.

11 Дьяченко А.Н. Химическая кинетика гетерогенных процессов: учеб. пос. / А.Н. Дьяченко, В.В. Шагалов. - Томск: Изд-во Том. политехн. ун-та, 2014. - 102 с.

12 Позин М.Е. Технология минеральных удобрений: учеб. / М.Е. Позин. - Л.: Химия, 1989. - 352 с.

\section{Г.М. Сейтмагзимова, А. Асылханқызы, И.А. Петропавловский, Ж.К. Джанмулдаева}

\section{Карналлит кенінен калий тыңайтқыштарын алу процесін зерттеу}

\begin{abstract}
Ішкі және сыртқы нарықты калий тыңайтқыштарымен қамтамасыз ету мақсатында Қазақстан осы өнімдердің меншікті өндірісін құра бастады. Бірақ қазіргі уақытта калий тұздарын өндіретін кәсіпорындар іс жүзінде ол кезеңге өткен жоқ. Карналлит кенінің Шалқар кен орны осы өзекті мәселелерді шешуде ерекшеленеді. Мақалада калий және магний сульфаттары бар калий тыңайтқышын алу үшін натрий хлоридінен жуылған калий кенін өңдеудегі зерттеу нәтижелері келтірілген. Карналлит кенінің азот қышқылымен ыдырау кинетикасы зерттелді. Калий сульфатының азот қышқылымен әрекеттесу реакциясының активтену энергиясының есептелген мәні процестің кинетикалық аймағын сипаттайды. Жуылған күйдірілген кенді концентрациясы 30 \% азот қышқылымен $50{ }^{\circ} \mathrm{C}$-та ыдыратудың оңтайлы шарттары анықталды. Сүзудің жақсы қасиеттерін және суспензияны бөлудің жоғары жылдамдығын қамтамасыз ету үшін гипс дегидратациясын болдырмау үшін жуылған күйдірілмеген кенді пайдалану керек екендігі анықталды, бұл оның ангидритке фазалық өзгеруін тудырады. Кристалдану арқылы азот қышқылы сығындысынан калий-магний сульфатының қос тұзы бөлінген және аммонизацияланған күңгірт сұйықтықты кептіргеннен кейін хлорсыз күрделі азот-калий-магний тыңайтқышы болып табылатын тұз алынады.
\end{abstract}

Кілт сөздер: калий кені, минералды тыңайтқыштар, калий сульфаты, натрий тұздары, Шалқар кен орны, күңгірт сұйықтық, ыдырау, булану, кристалдану.

Г.М. Сейтмагзимова, А. Асылханкызы, И.А. Петропавловский, Ж.К. Джанмулдаева

\section{Исследование процесса получения калийных удобрений из карналлитовых руд}

В целях обеспечения внутреннего и внешнего рынка калийными удобрениями Казахстан приступил к созданию собственного производства данной продукции. Однако в настоящий момент предприятия по 
добыче калийных солей не перешли в практическую стадию. Месторождение карналлитовых руд Челкар является уникальным в решении данных актуальных проблем. В статье приведены результаты исследования переработки отмытой от хлорида натрия калийной руды для получения калийного удобрения, содержащего сульфаты калия и магния. Исследована кинетика азотно-кислотного разложения карналлитовой руды. Рассчитанное значение энергии активации реакции взаимодействия сульфата калия с азотной кислотой характеризует кинетическую область протекания процесса. Определены оптимальные условия разложения отмытой прокаленной руды азотной кислотой концентрации $30 \%$ при $50{ }^{\circ} \mathrm{C}$. Установлено, что для обеспечения лучших фильтрующих свойств и высокой скорости разделения суспензии следует использовать отмытую непрокаленную руду для исключения дегидратации гипса, вызывающего фазовое превращение его в ангидрит. Кристаллизацией из азотнокислотной вытяжки выделена двойная соль сульфата калия-магния, и высушивание аммонизированного маточного раствора позволило получить соль, представляющую собой безбалластное бесхлорное сложное азотно-калийно-магниевое удобрение.

Ключевые слова: калийная руда, минеральное удобрение, сульфат калия, соли натрия, месторождение Челкар, маточный раствор, разложение, выпаривание, кристаллизация.

\section{References}

1 Zemskov, A.N. (2013). Tendentsii razvitiia kaliinoi promyshlennosti na sovremennom etape [Trends in the development of the potash industry at the present stage]. Trudy Natsionalnogo tsentra kompleksnoi pererabotki mineralnogo syrya Respubliki Kazakhstan - Proceedings of the National Center for Complex Processing of Mineral Raw Materials of the Republic of Kazakhstan, 1, 209-222 [in Russian].

2 Turko, M.R., Miskov, E.M., Stromskii, A.S., Kasenov, T.I., \& Sivtsov, K.V. (2014). Razrabotka tekhnologii obogashcheniia kaliinoi rudy mestorozhdeniia Satimola (Respublika Kazakhstan) [Development of potassium ore processing technology Satimol deposits (Republic of Kazakhstan)]. Gornyi zhurnal - Mining Journal, 2, 87-89 [in Russian].

3 Korneva, O. (2010). Kazakhstan: na zemnom share net takikh mestorozhdenii, gde boraty smeshany s magnievymi i kalievymi soliami [Kazakhstan: there are no deposits on the globe where borates are mixed with magnesium and potassium salts]. kazakhzerno.net https://kazakh-zerno.net/10009-kazakhstan-na-zemnom-share-net-takikh-mestorozhdenij-gde-boraty-smeshany-s-magnievymi-i-kalievymi-solyami/ [in Russian].

4 Savinskii, D. (2017). Kazakhstan pytaetsia probitsia v globalnyi kaliinyi klub [Kazakhstan is trying to break into the global potash club]. www.fertilizerdaily.ru https://www.fertilizerdaily.ru/20171205-kazaxstan-ne-mozhet-probitsya-v-globalnyj-kalijnyjklub/ [in Russian].

5 Ten, S. (2016). Zapasov khvatit let na sto [The reserves will last for a hundred years]. Gorno-metallurgicheskaia promyshlennost - Mining and Metallurgical Industry, 7, 32-34 [in Russian].

6 Seitmagzimova, G.M., Usenova, A.N., Asylkhankyzy, A., \& Seitmagzimov, A.A. (2018). Pererabotka karnallitovykh rud mestorozhdeniia Chelkar [Processing of carnallite ores of the Chelkar deposit]. Nauchnye trudy YuKGU im. M. Auezova-Scientific Works of M. Auezov SKSU, 4(48), 178-182 [in Russian].

7 Asylkhankyzy, A., Seitmagzimova, G.M., Petrov, M., \& Dzhanmuldaeva, Zh.K. (2020). Issledovanie sposobov pererabotki kaliinykh rud mestorozhdeniia Chelkar [Research of methods for processing Chelkar deposit potassium ores]. Vestnik KazakhstanskoBritanskogo tekhnicheskogo universiteta - Bulletin of the Kazakh-British Technical University, 2(53), 44-52 [in Russian].

8 Asylkhankyzy, A., Seitmagzimova, G.M., Petropavlovskii, I.A. (2021). Optimizatsiia protsessa obogashcheniia kaliinoi rudy mestorozhdeniia Chelkar [Optimization of the enrichment process of Chelkar deposit potassium ore]. Vestnik Kazakhstansko-Britanskogo tekhnicheskogo universiteta - Bulletin of the Kazakh-British Technical University, 1(18), 39-47 [in Russian].

9 Stefantsova, O.G., Rupcheva, V.A., \& Poilov, V.Z. (2014). Issledovanie tekhnologii polucheniia sulfatnykh kaliino-magnievykh udobrenii iz poligalitovykh rud [Research of the technology of obtaining sulfate potassium-magnesium fertilizers from polyhalite ores]. Vestnik PNIPU. Khimicheskaia tekhnologiia i biotekhnologiia - Bulletin of PNRPU. Chemical Technology and Biotechnology, 1, 65-74 [in Russian].

10 Kolinko, P.A., \& Kozlov, D.V. (2013). Khimicheskaia kinetika $v$ kurse fizicheskoi khimii [Chemical kinetics in the course of physical chemistry]. Novosibirsk: NGU [in Russian].

11 Dyachenko, A.N., \& Shagalov, V.V. (2014). Khimicheskaia kinetika geterogennykh protsessov [Chemical kinetics of heterogeneous processes]. Tomsk: Izdatelstvo Tomskogo politekhnicheskogo universiteta [in Russian].

12 Pozin, M.E. (1989). Tekhnologiia mineralnykh udobrenii [Mineral fertilizer technology]. Leningrad: Khimiia [in Russian].

\section{Information about authors:}

Seitmagzimova, Galina Manuilovna (corresponding author) - Candidate of technical sciences, Professor, M. Auezov South Kazakhstan University, Tauke khan, 5, 160012, Shymkent, Kazakhstan; e-mail: galinaseit@mail.ru; https://orcid.org/0000-0002-2357-626x

Assylkhankyzy, Aigerim - 3rd year PhD student, Department of Chemical Technology of Inorganic Substances, M. Auezov South Kazakhstan University, Tauke khan, 5, 160012, Shymkent, Kazakhstan; e-mail: asylkhankyzy092@mail.ru 
Petropavlovsky, IgorAlexandrovich - Doctor of technical sciences, Professor, D. Mendeleev University of Chemical Technology of Russia, Miusskaya square, 9, 125047, Moscow, Russian Federation, e-mail: ipetropavlovsky@gmail.ru

Dzhanmuldaeva, Zhanyl Kemaladinovna - Candidate of technical sciences, Professor, M. Auezov South Kazakhstan University, Tauke khan, 5, 160012, Shymkent, Kazakhstan, e-mail: zhanyld@mail.ru; https://orcid.org/0000-0002-7547-6519 